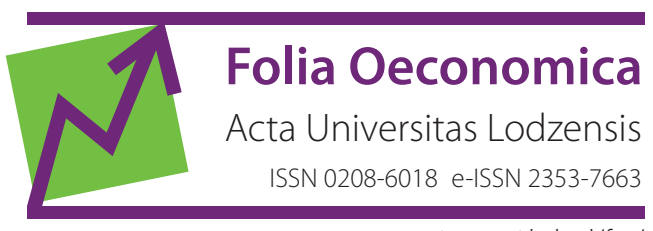

www.czasopisma.uni.lodz.pl/foe/

$1(327) 2017$

DOI: http://dx.doi.org/10.18778/0208-6018.327.04

\title{
Jan Michalak
}

Uniwersytet Łódzki, Wydział Zarządzania, Katedra Rachunkowości, janwmichalak@gmail.com

\section{Wskaźniki finansowe i niefinansowe w raportach strategicznych spółek z Wielkiej Brytanii - analiza z perspektywy oceny spółek przez inwestorów odpowiedzialnych społecznie}

\begin{abstract}
Streszczenie: Celem artykułu jest zbadanie stopnia zastosowania mierników dokonań prezentowanych w raportach strategicznych spółek wchodzących w skład indeksu FTSE techMARK oraz przeanalizowanie, czy mogą one służyć jako źródło użytecznych informacji do oceny spółek przez inwestorów stosujących strategie inwestowania społecznie odpowiedzialnego. Badaniem w formie analizy treści objętych zostało 60 spółek wchodzących w skład indeksu FTSE techMARK. Wyniki badania dowodzą, że wskaźniki finansowe i niefinansowe zawarte w raporcie strategicznym stanowią cenne źródło informacji dla inwestorów stosujących strategie inwestowania społecznie odpowiedzialnego. Wskaźniki niefinansowe zawarte w raportach strategicznych często mają charakter wskaźników wyprzedzających i mogą ułatwiać sporządzanie prognoz przyszłych zysków i przepływów pieniężnych spółek przez inwestorów. Pomagają one również w tworzeniu i modyfikowaniu portfeli inwestycyjnych przez inwestorów stosujących strategie inwestowania społecznie odpowiedzialnego.

Użyteczność raportów strategicznych dla inwestorów społecznie odpowiedzialnych do oceny spółek jest jednocześnie ograniczona przez różny format przedstawianych danych i stosunkowo duże zróżnicowanie wskaźników, co utrudnia ich porównywanie.
\end{abstract}

Słowa kluczowe: mierniki dokonań, raporty strategiczne, inwestowanie społecznie odpowiedzialne, użyteczność informacji

JEL: M41 


\section{Wprowadzenie}

Według J. Hollanda (1998) jednym z większych wyzwań sprawozdawczości przedsiębiorstw jest przedstawienie całościowego obrazu przedsiębiorstwa inwestorom w taki sposób, by możliwa była jego wszechstronna ocena. Prezentacji wszechstronnego obrazu jednostki, jej strategii i modelu biznesu dla spółek notowanych na Giełdzie Londyńskiej (LSE) służy raport strategiczny. Do oceny efektywności funkcjonowania spółek i ich oddziaływania na środowisko i społeczeństwo inwestorzy stosujący strategie inwestowania społecznie odpowiedzialnego mogą wykorzystywać mierniki dokonań zawarte w tych raportach.

Celem artykułu jest zbadanie stopnia zastosowania mierników dokonań prezentowanych w raportach strategicznych spółek wchodzących w skład indeksu FTSE techMARK oraz przeanalizowanie, czy mogą one służyć jako źródło użytecznych informacji do oceny spółek przez inwestorów stosujących strategie inwestowania społecznie odpowiedzialnego.

W artykule zostały przeanalizowane strategie inwestowania społecznie odpowiedzialnego oraz zidentyfikowane, na podstawie wcześniejszych badań, potrzeby informacyjne inwestorów stosujących te strategie. Następnie zaprezentowano strukturę raportu strategicznego, jego miejsce w raporcie rocznym, klasyfikacje mierników oraz dyskusję nad przydatnością różnych wskaźników dla inwestorów. W artykule przedstawiono ponadto metodykę badania, sposób doboru próby badawczej oraz wyniki badania empirycznego. W zakończeniu zawarto wnioski i wskazówki dotyczące kierunków dalszych badań.

\section{Strategie stosowane przez inwestorów społecznie odpowiedzialnych}

Inwestowanie społeczne dopowiedziane (ang. Socially Responsible Investing) powinno uwzględniać, oprócz czynników ekonomicznych, również kryteria społeczne, etyczne, religijne i ekologiczne (Dziawgo, 2010: 16). Inwestowanie takie ma długą historię. Już na początku XX wieku w Wielkiej Brytanii Kościół metodystów założył fundusz inwestycyjny, którego polityka zabraniała inwestowania w branże uznawane za grzeszne - powiązane $\mathrm{z}$ handlem bronią, alkoholem, przemysłem tytoniowym (Czerwonka, 2013: 18).

Tradycyjnie wyróżnia się dwie strategie inwestowania społecznie odpowiedzialnego - selekcję negatywną i selekcję pozytywną (Pogodzińska-Mizdrak, 2010: 178). Selekcja negatywna polega na rezygnacji z inwestowania w papiery wartościowe przedsiębiorstw mających niekorzystne oddziaływanie na społeczeń- 
stwo. Selekcja pozytywna oznacza inwestowanie w spółki wyróżniające się działaniami korzystnie wpływającymi na społeczeństwo.

Eurosif $^{1}$ wyróżnia aż siedem strategii inwestowania odpowiedzialnego społecznie: inwestycje zorientowane tematycznie na zrównoważony rozwój, selekcja najlepszych w danej kategorii, selekcja na podstawie norm, selekcja negatywna, integracja czynników ESG, zaangażowanie i inwestowanie z pozytywnym wpływem (inwestowanie społeczne).

Wielka Brytania jest jednym z największych rynków odpowiedzialnego inwestowania w Europie. Wyniki badań E. van Duurena i in. (2016) wskazują również, że więcej niż połowa zarządzających funduszami inwestycyjnymi w Wielkiej Brytanii (ze zbadanej przez nich grupy) wierzy, że istnieje pozytywny związek między stopami zwrotu i zastosowaniem strategii inwestowania społecznie odpowiedzialnego.

Według danych Eurosif za rok 2013 kwota inwestycji odpowiedzialnych społecznie w Wielkiej Brytanii wyniosła 2,893 bln funtów i wzrosła z 1,118 bln funtów w roku 2011. Struktura inwestycji odpowiedzialnych społecznie została przedstawiona na rysunku 1.

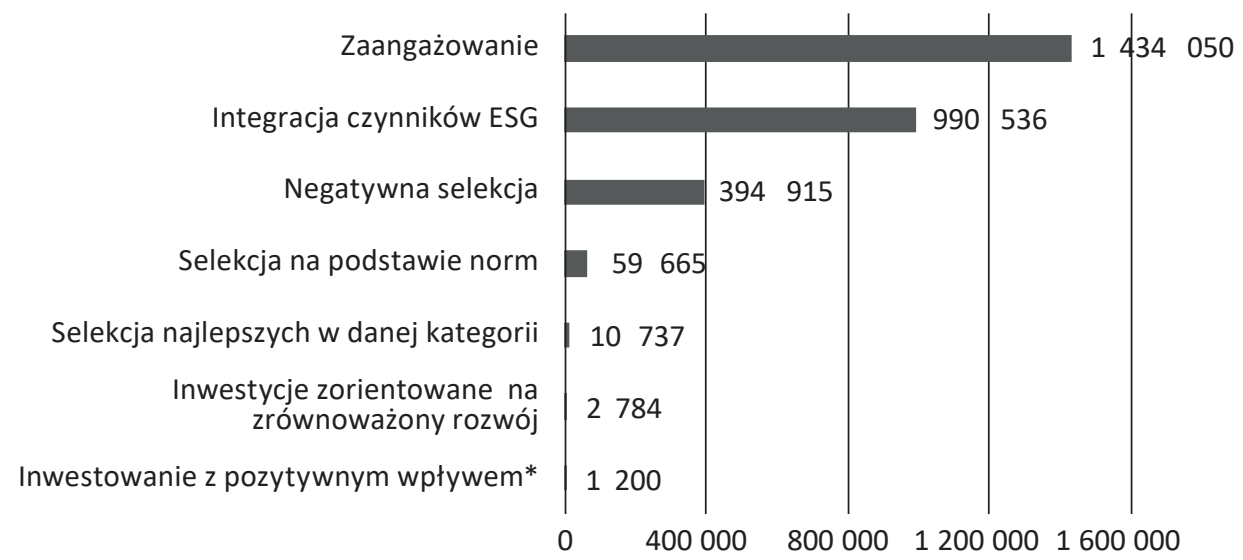

* Wartość inwestowania z pozytywnym wpływem jest prawdopodobnie znacznie zaniżona. Raport Eurosif nie uwzględnia inwestycji ze środków publicznych i z organizacji filantropijnych. Środki te stanowią główne źródła finansowania inwestycji z pozytywnym wpływem.

Rysunek 1. Struktura inwestycji odpowiedzialnych społecznie w Wielkiej Brytanii w 2013 roku w mln funtów

Źródło: opracowanie własne na podstawie Eurosif, 2014: 22 i 65

${ }^{1}$ European Sustainable Investment Forum - ogólnoeuropejska instytucja zajmująca się badaniem i popularyzowaniem inwestowania społecznie odpowiedzialnego. 
Analiza wykresu struktury inwestycji odpowiedzialnych społecznie w Wielkiej Brytanii (rys. 1) wskazuje, że największy udział mają strategie zaangażowania (49,55\% zainwestowanych środków), integracji ESG (34,23\% zainwestowanych środków), negatywnej selekcji (13,63\% zainwestowanych środków), selekcji na podstawie norm (2,06\% zainwestowanych środków). Można $\mathrm{z}$ tego wyciągnąć wniosek, że w Wielkiej Brytanii największe znaczenie mają strategie, dla których użyteczne są informacje o wpływie danego przedsiębiorstwa na społeczeństwo i środowisko (ponad 80\% zainwestowanych środków).

Dyskusja naukowa nad inwestowaniem społecznie odpowiedzialnym koncentrowała się dotychczas głównie na zagadnieniach efektywności portfeli opartych na różnych strategiach (zob. szerzej: Luther i in., 1992; Bauer i in., 2005; Brammer $\mathrm{i}$ in., 2006; Sandberg i in., 2009; Humphrey, Tan, 2014)². Obszerne badania literaturowe (Urban, 2011; Rogowski, Ulianiuk, 2012; Capelle-Blancard, Monjon, 2012) wskazują, że wpływ zastosowania strategii inwestowania społecznego na wyniki finansowe jest ograniczony i nieistotny statystycznie. Innym ważnym trendem w badaniach nad inwestowaniem społecznie odpowiedzialnym są czynniki wpływające na podejmowanie decyzji o realizacji inwestycji społecznie odpowiedzialnych (Rosen i in., 1991; Friedmann, Miles, 2001; Nilsson, 2008; Berry, Junkus, 2013; van Duuren i in., 2016).

Już na przełomie XX i XXI wieku A.L. Friedman i S. Miles (2001) na podstawie 14 wywiadów z ekspertami wykazali, że liczba i jakość ujawnień o wpływie przedsiębiorstw na społeczeństwo oraz inwestowanie społecznie odpowiedzialne są wzajemnie powiązane. Ich zdaniem zwiększony nacisk na uwzględnianie czynników etycznych przyczynia się do wzmożonego zapotrzebowania ze strony inwestorów na lepsze ujawnienia w zakresie wpływu przedsiębiorstw na społeczeństwo i środowisko. Nacisk ten wzmaga się również ze względu na rosnącą liczbę podmiotów stosujących strategie inwestowania społecznie odpowiedzialnego oraz zwiększającą się wartość zarządzanych przez nie aktywów. Z drugiej strony lepsza jakość ujawnień ESG przyczynia się do wzmacniania legitymizacji podmiotów raportujących i poziomu zaufania do nich oraz podnosi zainteresowanie inwestowaniem społecznie odpowiedzialnym.

T.C. Berry i J.C. Junkus (2013) przebadali 5391 inwestorów indywidualnych ze Stanów Zjednoczonych, zrzeszonych w American Association of Individual Investors - zarówno takich, którzy wskazali, że stosują, choć w części, strategie inwestowania społecznie odpowiedzialnego (1761), jak i pozostałych (3035). Czyn-

${ }^{2}$ Ze względu na to, że zagadnienie inwestowania społecznie odpowiedzialnego jest stosunkowo nowe oraz na fakt, iż strategie wymienione przez Eurosif mogą stosować zarówno inwestorzy instytucjonalni, jak i indywidualni, w przeglądzie literatury uwzględniono badania odnoszące się do obu grup inwestorów. Autor zdaje sobie sprawę z różnic w sposobach podejmowania decyzji przez inwestorów instytucjonalnych i indywidualnych. Pozostają one jednak poza zakresem rozważań niniejszego artykułu. 
nikami społeczno-środowiskowymi, które miały największy wpływ na podejmowane przez badanych decyzje inwestycyjne, były: wpływ na środowisko naturalne, zasady stosowane przez przedsiębiorstwa, produkty oferowane przez spółkę, aktywność społeczna, aktywność polityczna, zgodność z zasadami religii. W poszczególnych podkategoriach jako najbardziej istotne kwestie inwestorzy wskazali zagadnienia przedstawione w tabeli 1 .

Tabela 1. Znaczenie różnych czynników dla inwestorów

\begin{tabular}{|c|c|c|c|c|}
\hline Podkategoria & Środowisko & $\begin{array}{c}\text { Stosowane } \\
\text { zasady }\end{array}$ & $\begin{array}{l}\text { Aktywność } \\
\text { spoleczna }\end{array}$ & $\begin{array}{c}\text { Problemy } \\
\text { powodowane } \\
\text { przez produkty }\end{array}$ \\
\hline $\begin{array}{l}\text { Czynniki w ko- } \\
\text { lejności od naj- } \\
\text { ważniejszego } \\
\text { do najmniej } \\
\text { ważnego }\end{array}$ & $\begin{array}{l}\text { - Wyni- } \\
\text { ki wpływu } \\
\text { na środowi- } \\
\text { sko (efek- } \\
\text { tywność śro- } \\
\text { dowiskowa) } \\
\text { - Wpływ pro- } \\
\text { duktów } \\
\text { na środowi- } \\
\text { sko } \\
\text { - Zastosowa- } \\
\text { nie pestycy- } \\
\text { dów } \\
\text { - Żywność } \\
\text { modyfikowa- } \\
\text { na genetycz- } \\
\text { nie } \\
\text { - Wycinka } \\
\text { drzew } \\
\text { - Zagrożenie } \\
\text { nuklearne }\end{array}$ & $\begin{array}{l}\text { - Przestrzega- } \\
\text { nie prawa } \\
\text { - Zachowania } \\
\text { menedżerów } \\
\text { - Zarządzanie } \\
\text { łańcuchem } \\
\text { dostaw } \\
\text { - Corporate } \\
\text { Governance }\end{array}$ & $\begin{array}{l}\text { - Prawa pra- } \\
\text { cownicze } \\
\text { - Prawa czło- } \\
\text { wieka } \\
\text { - Bezpieczeń- } \\
\text { stwo pro- } \\
\text { duktu } \\
\text { - Bezpieczeń- } \\
\text { stwo pracy } \\
\text { - Inwestycje } \\
\text { w społecz- } \\
\text { ności } \\
\text { - Prawa zwie- } \\
\text { rząt } \\
\text { - Aktywność } \\
\text { polityczna, } \\
\text { zgodność } \\
\text { z zasadami } \\
\text { religii }\end{array}$ & $\begin{array}{l}\text { - Pornografia } \\
\text { - Tytoń } \\
\text { - Hazard } \\
\text { - Alkohol } \\
\text { - Broń palna } \\
\text { - Futra } \\
\text { - Niezdro- } \\
\text { we produkty } \\
\text { skierowane } \\
\text { do dzieci }\end{array}$ \\
\hline
\end{tabular}

Źródło: opracowanie własne na podstawie Berry, Junkus, 2013: 715-716

Nieoczekiwanym (niezgodnym z wcześniejszymi badaniami) wynikiem badań Berry'ego i Junkus (2013) był fakt, że inwestorzy w większym stopniu wykorzystują dane do wyboru (,nagradzania”) spółek, które wykazują pozytywny wpływ na środowisko, niż do selekcji negatywnej (wyłączania akcji spółek z portfela inwestycyjnego).

Badania prowadzone przez van Duurena i in. (2016) na próbie 126 menedżerów portfeli inwestycyjnych, głównie z Wielkiej Brytanii, Stanów Zjednoczonych oraz w mniejszym stopniu z innych krajów, wykazały, że większość badanych 
wykorzystuje informacje o wpływie przedsiębiorstwa na środowisko i społeczeństwo. Dane takie są w pierwszej kolejności używane do zarządzania ryzykiem, a następnie do: identyfikacji podmiotów, które są potencjalnie zagrożone (ang. red flagging), wyceny akcji, monitorowania akcji, a w najmniejszym stopniu do selekcji negatywnej. Badania van Duurena i in. (2016) wskazały również na istotne różnice w sposobie wykorzystania danych oraz w stopniu przekonania o wpływie zastosowania strategii inwestowania społecznie odpowiedzialnego na wyniki finansowe stosujących je funduszy inwestycyjnych między menedżerami pochodzącymi z różnych krajów świata. Menedżerowie z Europy (w tym z Wielkiej Brytanii) biorący udział w badaniu byli w większym stopniu przekonani o pozytywnym wpływie zastosowania takich strategii na wyniki finansowe inwestycji niż menedżerowie z USA.

\section{Wskaźniki finansowe i niefinansowe w raporcie strategicznym}

Wymóg ujęcia raportu strategicznego w sprawozdaniu rocznym został uchwalony przez parlament brytyjski w lipcu 2013 roku i zaczął obowiązywać dla raportów rocznych sporządzonych za rok obrotowy kończący się 30 września 2013 roku lub później. Według RRF raport roczny powinien składać się z następujących części: raportu strategicznego, raportu corporate governance, raportu o wynagrodzeniach członków zarządu i rady nadzorczej, sprawozdania finansowego, raportu zarządu o pozostałych kwestiach (tab. 2). Ani brytyjski Kodeks Ładu Korporacyjnego, ani Kodeks spółek nie zawierają dokładnych wskazówek, co powinien zawierać raport strategiczny. W 2014 roku RRF wydał Wytyczne w sprawie raportu strategicznego.

Raport strategiczny powinien, zgodnie z wspomnianymi wytycznymi, prezentować szereg zróżnicowanych informacji pozwalających zrozumieć bieżące i przyszłe funkcjonowanie jednostki oraz kontekst sprawozdań finansowych. Powinien on zawierać informacje o modelu biznesowym i strategii jednostki. Należy umieścić w nim analizy: przeszłych dokonań jednostki oraz głównych czynników ryzyka, a także sposób, w jaki mogą one wpłynąć na perspektywy rozwoju podmiotu. Raport strategiczny powinien wreszcie służyć jako drogowskaz pozwalający odnaleźć istotne informacje w pozostałych częściach raportu rocznego. W raporcie strategicznym są prezentowane trzy podstawowe obszary ujawnień:

1) zarządzanie strategiczne - sposób, w jaki jednostka zamierza generować i zachowywać wartość,

2) otoczenie biznesu - środowisko zewnętrzne i środowisko wewnętrzne, w którym jednostka funkcjonuje, 
3) dokonania podmiotu - osiągnięcia jednostki w danym okresie i jej sytuacja na koniec okresu.

Tabela 2. Struktura raportu rocznego według wytycznych RRF

\begin{tabular}{|c|c|c|c|c|c|}
\hline Dokument & \multicolumn{5}{|c|}{ Raport roczny } \\
\hline $\begin{array}{c}\text { Cel } \\
\text { dokumentu }\end{array}$ & \multicolumn{5}{|c|}{$\begin{array}{l}\text { Dostarczenie akcjonariuszom istotnych informacji, które są przydatne } \\
\text { do podejmowania decyzji o alokacji zasobów i oceny jakości sprawowa- } \\
\text { nia zarządu przez wyznaczone osoby (ang. directors'stewardship) }\end{array}$} \\
\hline $\begin{array}{c}\text { Części } \\
\text { skladowe }\end{array}$ & $\begin{array}{l}\text { Raport strate- } \\
\text { giczny }\end{array}$ & $\begin{array}{l}\text { Raport cor- } \\
\text { porate gov- } \\
\text { ernance }\end{array}$ & \begin{tabular}{|l|} 
Raport o wy- \\
nagrodze- \\
niach człon- \\
ków zarządu \\
i rady nad- \\
zorczej \\
\end{tabular} & $\begin{array}{l}\text { Sprawozda- } \\
\text { nie finanso- } \\
\text { we }\end{array}$ & $\begin{array}{l}\text { Raport za- } \\
\text { rządu o po- } \\
\text { zostałych } \\
\text { kwestiach } \\
\text { (ang. direc- } \\
\text { tor's report) }\end{array}$ \\
\hline $\begin{array}{l}\text { Cele części } \\
\text { skladowych }\end{array}$ & $\begin{array}{l}\text { Zapewnienie } \\
\text { kontekstu dla } \\
\text { sprawozdań } \\
\text { finansowych; } \\
\text { przedstawie- } \\
\text { nie strategii } \\
\text { i modelu biz- } \\
\text { nesu jednost- } \\
\text { ki; przed- } \\
\text { stawienie } \\
\text { głównych ry- } \\
\text { zyk, na któ- } \\
\text { re narażona } \\
\text { jest jednostka } \\
\text { oraz sposobu, } \\
\text { w jaki mogą } \\
\text { one wpłynąć } \\
\text { na przyszłe } \\
\text { funkcjonowa- } \\
\text { nie jednostki; } \\
\text { analiza do- } \\
\text { konań (ang. } \\
\text { performan- } \\
\text { ce) jednostki; } \\
\text { wskazanie lo- } \\
\text { kalizacji po- } \\
\text { szczególnych } \\
\text { informacji } \\
\end{array}$ & \begin{tabular}{|l|} 
Dostarcza- \\
nie informa- \\
cji umożli- \\
wiających \\
objaśnienie, \\
w jaki spo- \\
sób skład \\
i organiza- \\
cja struk- \\
tur nadzoru \\
korporacyj- \\
nego wspiera \\
osiągnięcie \\
celów jed- \\
nostki
\end{tabular} & \begin{tabular}{|l|} 
Przedstawie- \\
nie wszyst- \\
kich ele- \\
mentów \\
polityki usta- \\
lania wy- \\
nagrodzeń \\
członków \\
zarządu \\
i rady nad- \\
zorczej oraz \\
kluczowych \\
czynników, \\
które zosta- \\
ły uwzględ- \\
nione przy \\
ustalaniu tej \\
polityki
\end{tabular} & $\begin{array}{l}\text { Przedstawie- } \\
\text { nie sytuacji } \\
\text { finansowej } \\
\text { jednostki } \\
\text { i jej zmian } \\
\text { zgodnie } \\
\text { z obowiązu- } \\
\text { jącymi stan- } \\
\text { dardami ra- } \\
\text { chunkowości }\end{array}$ & $\begin{array}{l}\text { Dostarczenie } \\
\text { innych wy- } \\
\text { maganych } \\
\text { prawem, } \\
\text { standardami } \\
\text { lub dobrymi } \\
\text { praktykami } \\
\text { informacji } \\
\text { o spółce }\end{array}$ \\
\hline
\end{tabular}


W obszarze ujawnień dotyczącym zarządzania strategicznego ujmuje się opis strategii, celów oraz modelu biznesu. Opis modelu biznesu w raporcie strategicznym powinien umożliwić akcjonariuszom szerokie zrozumienie rodzaju relacji, zasobów i innych nakładów niezbędnych do osiągnięcia sukcesu przez przedsiębiorstwo. Należy jednocześnie podkreślić, że przedstawienie modelu biznesu jest kluczowe dla właściwej prezentacji.

Według wytycznych RRF w raporcie strategicznym należy zaprezentować najważniejsze silne strony jednostki oraz jej zasoby materialne i niematerialne (również takie zasoby niematerialne, które nie są wykazywane w bilansie podmiotu). Do ważnych aktywów niematerialnych, które - zdaniem autorów raportu - mogą być istotne dla akcjonariuszy, należą: reputacja, marka, baza lojalnych klientów, zasoby naturalne, pracownicy, zdolności badawczo-rozwojowe, kapitał intelektualny, licencje, patenty, prawa własności intelektualnej, znaki towarowe, pozycja rynkowa.

Ocenę efektywności funkcjonowania modelu biznesowego jednostki oraz stopnia realizacji strategii umożliwiają kluczowe mierniki dokonań (ang. Key Performance Indicators - KPI). Mierniki zawarte w raporcie strategicznym powinny być tymi, które zarząd uważa za szczególnie efektywne w ocenie postępu realizacji strategii, monitorowaniu podstawowych rodzajów ryzyka lub zmiany sytuacji jednostki. Wskazanym jest, żeby mierniki były powszechnie stosowane w branży - umożliwia to ich porównywanie między podmiotami, co w znacznym stopniu wpływa na ich użyteczność do oceny przez inwestorów. Opis mierników ujętych $w$ raporcie strategicznym powinien zawierać: definicję i sposób obliczania, cel, źródła danych wykorzystywanych do obliczania mierników, wszelkie ważne założenia przyjęte przy obliczaniu mierników, zmiany w sposobach obliczania w porównaniu do poprzednich lat, w tym zmiany w polityce rachunkowości wpływające na sprawozdania finansowe i obliczane na ich podstawie mierniki.

Zgodnie z zaleceniami RRF częścią raportu strategicznego jest prezentacja oddziaływania społecznego, charakteryzująca sposób, w jaki jednostka zamierza naprawić negatywne oddziaływanie na środowisko naturalne i społeczne lub sposób, w jaki przyczyniła się do jego poprawy. Raport strategiczny powinien również przedstawiać strukturę zatrudnionych według płci na koniec roku obrotowego, z uwzględnieniem osób będących członkami zarządu i rady nadzorczej, pracowników będących menedżerami wyższego szczebla, pracowników ogółem.

Wytyczne RRF zalecają wykorzystanie KPI w raportach strategicznych. Mierniki takie pozwalają na liczbowe przedstawienie procesów i zjawisk zachodzących w przedsiębiorstwie, ułatwiają ich prezentację i analizę. Stanowią one klasyczne narzędzia analityków finansowych pracujących na rzecz inwestorów oraz specjalistów rachunkowości zarządczej (controllerów), ponieważ dzięki nim możliwe jest prezentowanie informacji dla menedżerów i inwestorów w sposób zagregowany i łatwy do oceny. 
Najczęściej stosowanym w literaturze przedmiotu podziałem mierników dokonań jest rozróżnienie na mierniki finansowe i niefinansowe (por. Michalak, 2008). Stosowanie mierników finansowych, czyli wyrażonych w jednostkach pieniężnych lub w procentach (powstałych przez podzielenie dwóch wartości wyrażonych w jednostkach pieniężnych), posiada niewątpliwe zalety. Zachęca menedżerów do poszukiwania nowych sposobów realizacji istniejących procesów w celu poprawy wyników finansowych i - w konsekwencji - zwiększania bogactwa akcjonariuszy. Wykorzystanie mierników finansowych ma również wady. Powoduje ono mocną orientację menedżerów na wyniki krótkookresowe i redukcję analizy funkcjonowania przedsiębiorstwa wyłącznie do aspektów finansowych.

Mierniki niefinansowe są wyrażone w jednostkach naturalnych (np. sztukach, tonach) lub są opracowane na podstawie opinii (np. wskaźnik satysfakcji klientów). Wykorzystanie mierników niefinansowych pozwala przezwyciężać część słabości mierników finansowych. Ich stosowanie umożliwia pełniejsze odwzorowanie modelu biznesu przedsiębiorstwa i włączenie do analizy czynników mających wpływ na sukces przedsiębiorstwa dopiero w dłuższym okresie. Nie są one jednak pozbawione wad. Do ich najważniejszych ograniczeń należą: wyższe koszty zbierania danych, większa subiektywność i wynikająca z niej mniejsza wiarygodność.

Inną klasyfikacją mierników dokonań, zaproponowaną przez R.S. Kaplana i D. Nortona (2001), jest podział na mierniki wynikowe i mierniki wyprzedzające (przyszłego sukcesu). Te pierwsze charakteryzują sytuację przedsiębiorstwa w danym momencie. Należy do nich większość wskaźników finansowych, między innymi: wartość przepływów pieniężnych, wartość przedsiębiorstwa, kurs akcji, wartość dla akcjonariuszy (ang. shareholder value), ale również część wskaźników niefinansowych, takich jak: czas dostawy, jakość, wartość użytkowa produktu, cena. Wartość mierników wyprzedzających ma wpływ na sytuację przedsiębiorstwa w przyszłości. Wśród wskaźników przyszłego sukcesu Kaplan i Norton wyróżnili: zadowolenie i lojalność klientów, wskaźnik szybkości pozyskiwania nowych klientów, czas gotowości personelu, czas trwania cyklu produkcyjnego, wskaźnik odchyleń od standardów jakości, poprawa umiejętności personelu, liczba zgłaszanych innowacji.

Wykorzystanie mierników finansowych i niefinansowych upowszechnia się również w sprawozdaniach finansowych (i szerzej w raportach rocznych). Jest to zgodne z twierdzeniem I. Sobańskiej (2003) o wzajemnym przenikaniu się informacji finansowych i zarządczych w sprawozdaniu finansowym (raporcie rocznym), co skutkuje rozszerzeniem jego zakresu przedmiotowego.

Z punktu widzenia inwestorów stosujących strategie odpowiedzialne społecznie użyteczne jest uwzględnienie wskaźników niefinansowych i wyprzedzających w raportach rocznych, które pozwalają na zastosowanie strategii inwestowania społecznie odpowiedzialnego.

Podsumowując, na postawie analizy wytycznych RRF raport strategiczny można uznać za potencjalnie użytecznie źródło informacji dla inwestorów do oce- 
ny spółek, w tym dla inwestorów stosujących strategie integracji ESG i zaangażowania. Z punktu widzenia inwestorów stosujących strategie inwestowania społecznie odpowiedzialnego szczególnie użyteczne są mierniki niefinansowe, pozwalające ocenić wpływ przedsiębiorstw na społeczeństwo i środowisko. Z punktu widzenia takich inwestorów przydatna jest również informacja o modelu biznesu i o strategii. Sposób kreowania wartości przez spółkę może przyczyniać się do włączenia lub wyłączenia jej akcji do portfela akcji przez inwestora stosującego strategie inwestowania odpowiedzialnego społecznie. Przyczyną wyłączenia z portfela inwestycyjnego może być kreowanie wartości dla akcjonariuszy w sposób szkodliwy dla społeczeństwa, na przykład uzyskiwanie jej ze sprzedaży produktów, takich jak: broń, alkohol, wyroby tytoniowe.

\section{Metodyka i wyniki badania}

Badanie przedstawione $\mathrm{w}$ ramach artykułu miało charakter pilotażowo-eksploracyjny. Jako podstawową metodę badawczą przyjęto analizę treści (zawartości) raportów rocznych spółek notowanych na Londyńskiej Giełdzie Papierów Wartościowych. Zrealizowana analiza miała charakter jakościowo-ilościowy.

Badaniem zostały objęte spółki notowane na Londyńskiej Giełdzie Papierów Wartościowych, których akcje wchodzą w skład indeksu FTSE techMARK. Dzięki tej decyzji próba obejmuje w miarę jednorodne spółki z sektora wysokich technologii. Spółki wchodzące w skład indeksu FTSE techMARK są często podmiotami o dużym oddziaływaniu na społeczeństwo (na przykład spółki telekomunikacyjne i farmaceutyczne) oraz na środowisko (np. spółki biotechnologiczne, spółki zbrojeniowe).

W badaniu, w analizie treści skoncentrowano się na aspektach liczby i rodzaju mierników zawartych w raportach strategicznych. Badanie miało tym samym służyć odpowiedzi na następujące pytania badawcze:

1. Jakie kluczowe mierniki dokonań są zawarte w raporcie strategicznym?

2. Jaki jest udział kluczowych mierników finansowych i niefinansowych w raportach strategicznych?

3. Jakie mierniki są zawarte w części raportu strategicznego prezentującej wpływ na społeczeństwo i środowisko?

4. W jakim stopniu mierniki zawarte w raportach strategicznych pozwalają na ocenę stopnia ich oddziaływania na społeczeństwo i środowisko przez inwestorów społecznie odpowiedzialnych?

Indeks FTSE techMARK obejmuje 60 spółek z sektora wysokich technologii. Badaniu zostały poddane raporty roczne za 2013 rok. Uwzględniono w nim mierniki określone jako kluczowe mierniki dokonań (KPI), a także wskaźniki nieokreślone jako strategiczne i publikowane w części poświęconej oddziaływaniu na społeczeństwo i środowisko. 
Wszystkie badane przedsiębiorstwa postąpiły zgodnie z wytycznymi RRF i ujęły w raportach strategicznych kluczowe mierniki dokonań (KPI). Liczba mierników prezentowanych w raportach strategicznych była zróżnicowana - wahała się od 4 w przypadku spółki Vectura do 19 w przypadku spółki Astra Zeneca. Średnia liczba kluczowych mierników dokonań wynosiła 8, a dominantą było 6 mierników. Wyraźnie częściej stosowane były mierniki finansowe (średnio 6) niż mierniki niefinansowe (średnio 2). Co więcej, aż 19 spółek (32\% badanych podmiotów) w raportach strategicznych do oceny stopnia wdrożenia strategii i efektywności funkcjonowania modelu biznesu wykorzystało wyłącznie wskaźniki finansowe.

Najczęściej ujawnianym w raportach strategicznych miernikiem dokonań była całkowita wartość przychodów - zawarta w raportach 57\% badanych spółek. Informacje o przychodach były ponadto przedstawiane jako kluczowe mierniki dokonań w przekroju najważniejszych z punktu widzenia realizacji strategii:

1) rodzajów/segmentów działalności, np. przychody z działalności rozwojowej prowadzonej dla klientów, przychody ze sprzedaży danych;

2) rynków, np. rynków wschodzących, rynków, na których działalność firmy nie jest zagrożona ze względów prawnych;

3) grup produktów, np. nowych produktów, produktów przyjaznych dla środowiska (ang. green products).

Innymi często prezentowanymi $\mathrm{w}$ raportach strategicznych miernikami finansowymi były: zysk na akcję - EPS (40\%), zysk operacyjny (33\%), dynamika sprzedaży (25\%), EBITDA (23\%), wydatki na badania i rozwój (20\%), wskaźnik konwersji gotówki (20\%), marża zysku operacyjnego (18\%), zysk brutto (17\%), przepływy pieniężne z działalności operacyjnej (15\%), dywidenda na akcję (13\%), środki pieniężne netto $(12 \%)$, organiczny wzrost przychodów $(12 \%)$, wartość portfela zamówien $(8 \%)$, przepływy pieniężne netto (8\%), stopa zwrotu z zaangażowanego kapitału (8\%). Niektóre spółki ujęły w swoich raportach strategicznych wskaźniki specyficzne dla ich sektora, np. MCEV, IGD, lub specyficzne dla ich modelu biznesu, np. zysk operacyjny przypadający na rynkowy ekwiwalent świni.

Wskaźniki niefinansowe prezentowane w raportach strategicznych badanych spółek cechowały się jeszcze większym zróżnicowaniem. Jedynie kilka z nich powtarzało się w raportach. Do tych relatywnie często występujących należały: liczba pracowników $(10 \%)$, liczba wypadków (10\%), wskaźnik rotacji pracowników (8\%), poziom emisji $\mathrm{CO}_{2}(7 \%)$, wskaźnik zaangażowania pracowników (5\%), wskaźnik satysfakcji klientów (5\%), czas pracy utracony na skutek wypadków (5\%), liczba osiągniętych głównych celów (5\%), liczba nowych produktów (ang. Net Promoter Score - NPS) (5\%), liczba patentów (3\%), liczba przejęć (3\%). Pozostałe wskaźniki były bardzo zróżnicowane i dostosowane do strategii lub modelu biznesu przedsiębiorstwa - np. udział architektury ARM w smartfonach czy liczba wakatów zapełnionych na drodze wewnętrznej rekrutacji. 
W części raportów strategicznych występowała większa liczba wskaźników niefinansowych, ale były one zawarte w części dotyczącej oddziaływania na środowisko i społeczeństwo (CSR). Wśród mierników oddziaływania na środowisko (prezentowanych w tej części) najbardziej rozpowszechnione były: ilość emitowanego $\mathrm{CO}_{2}$ (zarówno bezpośrednio, jak i pośrednio) oraz powiązane z nimi mierniki intensywności, takie jak ilość wyemitowanych ton $\mathrm{CO}_{2}$ na $1 \mathrm{mln}$ przychodów, na 1 pracownika, na GJ zużytej energii. Wskaźniki takie zostały zaprezentowane w raportach strategicznych 56 z 60 (93\%) badanych przedsiębiorstw, a w dwóch kolejnych wystąpiło odesłanie do innych dokumentów, w których takie dane są dostępne. Innymi stosunkowo często prezentowanymi w raportach strategicznych miernikami oddziaływania na środowisko były: zużycie energii, zużycie wody, ilość śmieci przekazanych na składowiska, ilość śmieci poddanych recyklingowi, ilość śmieci niebezpiecznych dla środowiska oraz procent zmniejszenia zużycia zasobów (np. energii elektrycznej, powierzchni).

Najczęściej prezentowanymi miernikami w zakresie bezpieczeństwa i higieny pracy były: liczba wypadków, liczba wypadków w relacji do liczby pracowników lub czasu pracy, czas pracy utracony na skutek wypadków. Zróżnicowanie pod względem płci zostało uwzględnione w raportach strategicznych wszystkich badanych spółek. Najczęściej spółki ujawniały zróżnicowanie na trzech poziomach: zarządu (i rady nadzorczej), menedżerów wyższego szczebla oraz ogółu pracowników. W części przypadków zdarzały się ujawnienia mniej szczegółowe - np. informacja tylko na temat zróżnicowania zarządu (i rady nadzorczej) oraz ogółem. Niektóre podmioty uwzględniały również dodatkowy, czwarty poziom - zróżnicowanie na poziomie zarządów (i rad nadzorczych) w poszczególnych spółkach wchodzących w skład grupy kapitałowej. Stosunkowo niewielka część spółek prezentowała również zróżnicowanie pracowników pod względem wieku, lokalizacji geograficznej, a nawet udziału mniejszościowych grup etnicznych w liczbie zatrudnionych.

Interesującym trendem wśród mierników niefinansowych zamieszczanych w raportach strategicznych była prezentacja wskaźników podwójnych korzyści (dual benefits indices), czyli takich wskaźników niefinansowych, które są jasno powiązane ze wskaźnikami finansowymi. Przykładem takiego miernika jest dynamika zużycia energii elektrycznej. Redukcja zużycia energii elektrycznej jest dobra dla środowiska (pierwsza korzyść) i jednocześnie zmniejsza koszty i poprawia wyniki podmiotu (druga korzyść).

Wskaźniki niefinansowe ujawnianie w raportach strategicznych były często wskaźnikami wyprzedzającymi według klasyfikacji zaproponowanej przez Kaplana i Nortona (2001). Informacje o rosnącej liczbie wypadków, zwiększonym negatywnym oddziaływaniu na środowisko czy obniżających się wskaźnikach NPS i malejącej liczbie patentów mogą być dla inwestorów podstawą do prognozowania gorszych wyników finansowych w przyszłości. Może to wpływać na wyklu- 
czenie akcji danej spółki z portfela inwestycyjnego inwestora ze względu na złe oddziaływanie na środowisko i społeczeństwo oraz możliwość pogorszenia się sytuacji finansowej jednostki w przyszłości. Inwestorzy, zwłaszcza stosujący strategie inwestowania społecznie odpowiedzialnego, wykorzystują dane niefinansowe do wyboru spółek, które wykazują pozytywny wpływ na środowisko, a osiągają zbliżone wyniki finansowe.

Zawarte w raportach strategicznych ujawnienia o charakterze jakościowym, na przykład te o modelu biznesu, również stanowiły potencjalnie użyteczne źródło informacji dla inwestorów odpowiedzialnych społecznie. Społecznie odpowiedzialne fundusze inwestycyjne stosujące strategię selekcji negatywnej na podstawie informacji o modelu biznesowym spółek BAE i Meggit mogą podjąć decyzję o ich wykluczeniu z portfela inwestycyjnego, ponieważ podmioty te wytwarzają podzespoły uzbrojenia.

\section{Podsumowanie}

Wielka Brytania jest wiodącym w Europie i na świecie rynkiem inwestowania społecznie odpowiedzialnego. Najczęściej stosowanymi strategiami inwestowania społecznie odpowiedzialnego w tym kraju są zaangażowanie i integracja ESG. Na podstawie zrealizowanych badań można stwierdzić, że dla inwestorów stosujących takie strategie raport strategiczny (który od niedawna jest wymaganą częścią raportu rocznego w Wielkiej Brytanii) stanowi potencjalnie użyteczne źródło informacji z następujących przyczyn. Po pierwsze, wskaźniki finansowe i niefinansowe pozwalające na odzwierciedlenie wpływu na społeczeństwo i środowisko są ujawniane w raportach wszystkich badanych spółek. Po drugie, w raportach strategicznych dominują finansowe kluczowe mierniki wyników, co świadczy o tym, że wyniki finansowe pozostawały, zdaniem sporządzających raporty roczne, kluczowymi informacjami dla inwestorów. Po trzecie, miernikami zawartymi w raportach strategicznych, pozwalającymi na ocenę działalności spółki w zakresie oddziaływania na środowisko i społeczeństwo, są głównie niefinansowe mierniki dokonań. Po czwarte, najpowszechniejszymi miernikami niefinansowymi zawartymi w raportach strategicznych umożliwiających prowadzenie analiz ESG są takie wskaźniki, jak: emisja gazów cieplarnianych i zróżnicowanie pracowników. Przyczyną ich częstego występowania był prawdopodobnie fakt ich wymagania przez prawo w Wielkiej Brytanii. Innymi wskaźnikami niefinansowymi przydatnymi dla inwestorów społecznie odpowiedzialnych, prezentowanymi w raportach strategicznych, są między innymi: liczba wypadków, liczba wypadków w relacji do liczby pracowników, ilość odpadów czy zużytej energii. Po piąte, wskaźniki niefinansowe zawarte w raportach strategicznych, mające charakter wskaźników wyprzedających, mogą ułatwiać sporządzanie prognoz przyszłych 
zysków i przepływów pieniężnych spółek przez inwestorów. Pomagają one również w tworzeniu i modyfikowaniu portfeli inwestycyjnych przez inwestorów, zwłaszcza stosujących strategie inwestowania społecznie odpowiedzialnego.

Można również zidentyfikować czynniki ograniczające przydatność raportów strategicznych dla inwestorów stosujących strategie społecznej odpowiedzialności. Są to: różny format przedstawianych danych i wykorzystanie odmiennych wskaźników. Wcześniejsze badania, przeprowadzone przez van Duurena i in. (2016), wskazują, że inwestorzy stosujący strategię integracji ESG mogą w związku z tym poszukiwać informacji ze źródeł wtórnych, które są łatwiejsze do porównań. Źródłami wtórnymi wykorzystywanymi przez inwestorów są oceny agencji ratingowych ESG i raporty analityków dotyczące poszczególnych spółek. Zweryfikowanie hipotezy o dużej użyteczności raportów strategicznych dla inwestorów społecznie odpowiedzialnych do oceny spółek wymaga dalszych badań - m.in. uwzględniających stopień wykorzystania danych ujawnianych w raportach strategicznych o wpływie na społeczeństwo i środowisko przez agencje ratingowe i analityków.

\section{Bibliografia}

Bauer R., Koedijk K., Otten R. (2005), International evidence on ethical mutual fund performance and investment style, ,Journal of Banking and Finance”, vol. 29(7), s. 1751-1767.

Berry T.C., Junkus J.C. (2013), Socially responsible investing: An investor perspective, „Journal of Business Ethics", vol. 112(4), s. 707-720.

Brammer S., Brooks C., Pavelin S. (2006), Corporate social performance and stock returns: UK evidence from disaggregate measures, „Financial Management”, vol. 35(3), s. 97-116.

Capelle-Blancard G., Monjon S. (2012), Trends in the literature on socially responsible investment: Looking for the keys under the lamppost, „Business Ethics: A European Review”, vol. 21, s. $239-250$.

Czerwonka M. (2013), Inwestowanie społecznie odpowiedzialne, Difin, Warszawa.

Duuren E. van, Plantinga A., Scholtens B. (2016), ESG integration and the investment management process: fundamental investing reinvented, „Journal of Business Ethics”, vol. 138(3), s. $525-533$.

Dziawgo L. (2010), Zielony rynek finansowy. Ekologiczna ewolucja rynku finansowego, PWE, Warszawa.

Eurosif(2014), European SRI Study 2014, http://www.eurosif.org/wp-content/uploads/2014/09/Eurosif-SRI-Study-20142.pdf [dostęp: 1.03.2016].

FRC (2014), Guidance on the Strategic Report, https://frc.org.uk/Our-Work/Publications/Accounting-and-Reporting-Policy/Guidance-on-the-Strategic-Report.pdf [dostęp: 15.03.2016].

Friedman A.L., Miles S. (2001). Socially responsible investment and corporate social and environmental reporting in the UK: an exploratory study, „The British Accounting Review”, vol. 33(4), s. 523-548.

Holland J. (1998), Private disclosure and financial reporting, „Accounting and Business Research”, vol. 28(4), s. 255-269.

Humphrey J.E., Tan D.T. (2014), Does it really hurt to be responsible?, „Journal of Business Ethics”, vol. 122, s. 375-386. 
Kaplan R.S., Norton D. (2001), Strategiczna karta wyników - Jak przełożyć strategię na działania, PWN, Warszawa.

Luther R.G., Matatko J., Corner D.C. (1992), The investment performance of UK, ,ethical” Unit Trusts, „Accounting, Auditing and Accountability Journal”, vol. 5(4), s. 57-70.

Michalak J. (2008), Pomiar dokonań. Od wyniku finansowego do Balanced Scorecard, Difin, Warszawa.

Nilsson J. (2008), Investment with a conscience: Examining the impact of pro-social attitudes and perceived financial performance on socially responsible investment behaviour, „Journal of Business Ethics", vol. 83, s. 307-325.

Pogodzińska-Mizdrak E. (2010), Koncepcje społecznie odpowiedzialnego gospodarowania $i$ inwestowania szansa rozwoju rachunkowości, „Zeszyty Teoretyczne Rachunkowości”, t. 56, s. $175-184$.

Rogowski W., Ulianiuk A. (2012), Społecznie odpowiedzialne inwestowanie (SRI) - próba charakterystyki, „Studia Prace Kolegium Zarządzania”, nr 114, s. 64-81.

Rosen B.N., Sandler D.M., Shani D. (1991), Social issues and socially responsible investment behavior: A preliminary empirical investigation, „Journal of Consumer Affairs”, vol. 25(2), s. 221-234.

Sandberg J., Juravle C., Hedesström T.D., Hamilton I. (2009), The heterogeneity of socially responsible investment, „Journal of Business Ethics”, vol. 87, s. 519-533.

Sobańska I. (2003), Problemy rachunkowości zarzadczej w grupie kapitałowej-nowy obszar badawczy, „Zeszyty Teoretyczne Rachunkowości”, t. 17, s. 110-120.

Urban D. (2011), Zarys koncepcji inwestowania spolecznie odpowiedzialnego, „Acta Universitatis Lodziensis. Folia Oeconomica", nr 261, s. 495-507.

\title{
The financial and non-financial performance indicators in strategic reports of companies from the UK - relevance from the perspective of socially responsible investors
}

\begin{abstract}
The article aims to investigate which performance indicators are revealed in strategic reports of companies listed on the London Stock Exchange whether they can constitute relevant source of information to evaluate companies for investors using socially responsible investment strategies. The research method used in the article is content analysis of 60 reports of companies included in the FTSE techMARK. The research results indicate that the strategic report is a potentially relevant source of information for investors using ESG integration and commitment strategies, that dominate in the UK. Non-financial KPI, disclosed in strategic reports, are often leading indicators and may facilitate the preparation of forecasts of future profits and cash flows of companies by investors. They also help in the creation and adjustments of investment portfolios by investors using socially responsible investment strategies.

Usefulness of strategic reports for socially responsible investors is, however, limited by different format of the presented data and the relatively high variety of indicators, that makes them difficult to compare.
\end{abstract}

Keywords: key performance indicators, strategic report, socially responsible investment

JEL: M41 


\begin{tabular}{|l|l|}
\hline \multirow{2}{*}{ OPEN ACCESS } & $\begin{array}{l}\text { C by the author, licensee Łódź University - Łódź University Press, Łódź, Poland. } \\
\text { This article is an open access article distributed under the terms and conditions } \\
\text { of the Creative Commons Attribution license C(-BY } \\
\text { (http://creativecommons.org/licenses/by/3.0/) }\end{array}$ \\
\cline { 2 - 3 } \\
Received: 2016-06-09; verified: 2016-11-03. Accepted: 2017-02-20
\end{tabular}

